\title{
A representação do homossexual no discurso humorístico: uma análise do canal "Porta dos Fundos"
}

\author{
Homossexual representation in humorous speech: \\ an analysis of "Porta dos Fundos" YouTube channel
}

Nilton César Ferreira

Centro Universitário "Antônio Eufrásio de Toledo" de Presidente Prudente/SP nc.ferreirah@hotmail.com

Alexandre Sebastião Ferrari Soares

Universidade Estadual do Oeste do Paraná

asferraris@globo.com

Resumo: O presente artigo objetiva analisar os efeitos de sentidos do discurso humorístico acerca da homossexualidade masculina e da chamada "proposta de cura gay" apresentada por um segmento conservador do cristianismo brasileiro. A metodologia adotada foi a Análise do Discurso de orientação francesa. $\mathrm{O}$ trabalho está organizado da seguinte maneira: primeiro, examinamos a relação entre o discurso, o humor e as piadas; em seguida, apresentamos uma breve contextualização sobre a homossexualidade enquanto categoria; e, por fim, analisamos um corpus de um esquete publicado pelo canal "Porta dos Fundos", cujo título é "Cura". É possível depreender da análise que os temas acerca do humor constituem-se em veículos de produção e reprodução de ideologias e que o discurso em estudo apresenta um contraponto em relação aos dizeres que mobilizam as práticas não heterossexuais como contingente e moralmente condenáveis. Observamos, inclusive, que as falas enunciadas pelas personagens na produção humorística contrapõem os discursos religioso, médico e patriarcal, permitindo uma reflexão a respeito das cristalizações sobre o que é ser gay. 
Palavras-chave: Análise do Discurso; Humor; Ideologia; Homossexualidade masculina; Cura gay.

Abstract: This paper analyses, through the French Discourse Analysis point of view, the meaning effects of humorous speech on male sexuality and the Conversion Therapy disseminated by a conservative wing of Brazilian Christianity. The work is organized as follows: first, the relationship between speech, humour and jokes; then a brief background of homosexuality as a category is presented; and finally, the corpus of a Brazilian YouTube channel "Porta dos Fundos" sketch - "The Cure" - is analyzed. It is possible to conclude that the linguistic themes from comic speech are means of production and reproduction of an ideology and that the investigated discourse is a contrasting element about the sayings of non-heterosexual contingent and morally reprehensible practices. It has been noticed that the lines spoken by the characters in the comical production disagree with the religious, medical and patriarchal discourses, allowing a reflection on the crystallization of what means to be gay.

Keywords: Discourse Analysis; Humour; Ideology; Male homosexuality; Conversion Therapy.

Recebido em: 12 de abril de 2016.

Aprovado em: 20 de junho de 2016.

\section{Introdução}

Os textos de humor têm sido apresentados como um domínio privilegiado para a manifestação inconsciente de uma ideologia calcada na homofobia ${ }^{1}$ fenômeno amplamente observado no Ocidente. Tanto é que a imagem dos homossexuais é construída tipicamente, por exemplo, nas piadas, por meio de contendas e dissensões ideológicas e sociais. Isto não significa, porém, que tais textos não possam servir como um espaço de contraponto, de ruptura, em relação aos discursos que significam como contingente e moralmente condenáveis as práticas não heterossexuais.

\footnotetext{
${ }^{1}$ A palavra "homofobia", cuja origem remete às pesquisas do psicólogo estadunidense George Weinberg (1972), nos anos setenta do século passado, é usada para definir o preconceito contra os sujeitos homossexuais.
} 
No presente trabalho, pretendemos refletir acerca dos efeitos de sentido que circulam sobre a homossexualidade, ${ }^{2}$ buscando compreender como o discurso humorístico funciona como veículo de ideologias e como estas apropriam-se de outros discursos para significar o sujeito homossexual. Neste sentido, as produções de humor são de fato um excelente corpus para verificar de que modo este sujeito circula, a partir de uma visão que se importa em questionar não apenas o conservadorismo religioso, mas também a concepção que preconiza uma possibilidade de "cura" da homossexualidade.

Para tanto, escolhemos um esquete humorístico ${ }^{3}$ intitulado como "Cura", ${ }^{4}$ publicado em 9 de setembro de 2013, no site "Porta dos Fundos" - definindo-se como corpus para análise o discurso em resposta ao Projeto de Decreto Legislativo n. ${ }^{\circ}$ 234/11, popularmente conhecido como "Cura Gay", que buscava suspender os artigos 3. ${ }^{\circ}$ e 4 . $^{\circ}$ da Resolução n. ${ }^{\circ}$ 01/99 do Conselho Federal de Psicologia e, logo, tornar a "homossexualidade" como uma "patologia" passível de "tratamento". A metodologia adotada neste artigo, para a compreensão dos efeitos de sentidos sobre a homossexualidade, consiste na análise de sequências discursivas, a partir do esquete "Cura", de forma a compreender o funcionamento ideológico dos discursos que se instalam nos modos de dizer sobre a homossexualidade e o homossexual.

O corpus suprarreferido não é "neutro", até porque só existem piadas sobre temas que são socialmente controversos, consistindo num material importante, devido a forma de sua circulação, para se apreender determinadas manifestações culturais e ideológicas (POSSENTI, 1998, p. 25). Sendo a realidade edificada através da língua(gem), a árdua tarefa do analista do discurso consiste em desvelar os lugares discursivos de onde partem os sentidos (GONÇALVES; FERREIRA, 2014, p. 197).

${ }^{2}$ É importante ressaltar que estamos falando especificamente da homossexualidade no Brasil (sobretudo da homossexualidade masculina).

${ }^{3}$ Os esquetes humorísticos, de acordo com Luiz Antônio Marcuschi (2008, p. 199), são um gênero emergente na mídia eletrônica (rádio, televisão e internet) e, embora possuem características próprias, têm como um contraparte em gênero preexistente as piadas. Em virtude disso, consideraremos o nosso objeto de análise, para fins do presente trabalho, como sendo caracteristicamente piadístico.

${ }^{4}$ CURA. Porta dos Fundos. 09/09/2013. Disponível em: <http://www.portadosfundos. com.br/video/cura $>$. Acesso em: 04 abr. 2015. (audiovisual) 
Neste diapasão, o artigo está organizado da seguinte maneira: na próxima seção, examinamos a relação entre o discurso e o humor; na seção 3, apresentamos uma abordagem teórica a respeito do riso, sob uma perspectiva filosófica; na seção 4 , discutimos a relação entre o inconsciente e os chistes; na seção 5, apresentamos um breve histórico sobre a homossexualidade; na seção 6 , procedemos a análise propriamente dita, descortinando os significados produzidos no esquete humorístico; na seção 7, temos as considerações finais.

\section{Do ponto de vista linguístico, o humor e as piadas}

De acordo com Possenti (2010, p. 103), o humor incide em uma esfera onde circulam diversos gêneros, dentre os quais, as piadas. Tal esfera abrange praticamente todos os tipos de temas. O que se faz por meio de muitos gêneros, da comédia à charge. A partir daí, as produções humorísticas são conceituadas de acordo com o pensamento de Mikhail Bakhtin (2011, p. 262), quer dizer, como enunciados relativamente estáveis, marcados por "seu conteúdo, seu estilo e sua composição".

Com o intuito de situar as piadas enquanto efeitos de sentidos e gênero de discurso, Possenti (2010, p. 104) recorre às contribuições de Raskin (1985). O qual considera como basilar, para que um texto seja constituído como piadístico, a presença de dois scripts que se opõem e, ao mesmo tempo, são compatíveis. O "gatilho", por sua vez, é o que permite acionar uma interpretação, por exemplo, não esperada, estabelecendo a passagem de um script a outro. Contudo, as piadas não são de fácil classificação, de modo que algumas não apresentem as características requeridas por Raskin (POSSENTI, 2010, p. 105).

Os discursos explorados nas piadas, de acordo com Possenti (1998), são temas socialmente controversos, os quais pontuam visões estereotipadas sobre um problema (p. 25-26). Assim, as temáticas abrangidas no espaço das piadas encontram-se arraigadas no imaginário popular, como parte da memória e da identidade de uma sociedade. Desta forma, as piadas tendem a representar, por exemplo, os homossexuais masculinos, inseridos na história das sociedades ocidentais, como promíscuos, caricatos, efeminados.

Para Possenti (1998), as piadas são interessantes, pois veiculam quase sempre um discurso proibido, não oficial. Sendo assim, o discurso humorístico "consegue dizer o que não pode/deve ser dito" (p. 26). 
Somente nas piadas, certos temas, como o racismo, a homossexualidade, a obesidade, entre outros, são possíveis de circular sem um tratamento cauteloso. De uma forma geral, estes temas reclamam os sentidos estabelecidos a partir do que é permitido dizer, ou seja, há uma interdição social em relação a eles.

O discurso humorístico não deve ser visto simplesmente como instrumento de diversão, pois se constitui como suporte para as diversas manifestações culturais e ideológicas. Assim sendo, o discurso tem a sua regularidade, o seu funcionamento, que é possível apreender "se não opomos o social e o histórico, o sistema e a realização, o subjetivo ao objetivo, o processo ao produto" (ORLANDI, 2000, p. 22). De tal modo, as produções de humor exigem ser tomadas não apenas no seu contexto imediato de produção, mas como "efeito de sentidos entre interlocutores" (PÊCHEUX, 1997, p. 82).

Vale a pena lembrar que os temas acerca do humor e do riso, os quais já estavam em voga na segunda metade do século XIX, não interessam apenas à Teoria do Discurso. A partir daí, torna-se imprescindível uma releitura sobre as obras dos principais teóricos, que se dedicaram ao estudo dos referidos temas, dentre os quais, Bergson (1978) e Freud (2006).

\section{Do ponto de vista da filosofia, o riso}

No campo da filosofia, Bergson (1978), em sua obra "O Riso", publicada originalmente em 1899 , define o ato de rir como um traço distintivo do próprio homem (BERGSON, 1978, p. 12). Dessa forma, a palavra "veado", por exemplo, só desperta risos devido às características que lhe atribuímos, associando ao homossexual masculino.

Para Bergson (1978), a insensibilidade é o ambiente natural do riso. Isto não significa que não se possa rir de alguém que inspire piedade, ou até mesmo afeição. No caso, "será preciso esquecer por alguns instantes essa afeição, ou emudecer essa piedade" (BERGSON, 1978, p. 12). Sendo assim, as piadas que significam, por exemplo, os homossexuais masculinos com traços efeminados, despertam risos inclusive do próprio público GLBTTT (gays, lésbicas, bissexuais, travestis, transexuais e transgêneros), o que pode caracterizar a insensibilidade em questão.

Por sua vez, o riso não se trata de um som articulado, nítido e acabado, visto que "o nosso riso é sempre o riso de um grupo" 
(BERGSON, 1978, p. 13). O que implica considerar que a graça de uma piada não reside tão somente numa determinada técnica, numa quebra de expectativa ou na presença de um "gatilho". Sendo assim, o riso exige ser compreendido em seu ambiente natural, quer dizer, a sociedade (p. 14).

Nesta confluência, o riso não é provocado pela queda de quem tropeçou, mas pelo desajeitamento de quem caiu, ou seja, o alvo é a pessoa. Assim, o riso presta-se a uma finalidade punitiva e corretiva (BERGSON, 1978, p. 13-14), de modo que os textos humorísticos permitem à sociedade castigar certos defeitos, "como a doença castiga certos excessos, atingindo inocentes" (p. 99). Desta forma, o riso tem a função de intimidar humilhando (p. 100).

\section{Do ponto de vista da psicanálise, os chistes}

O pensamento de Bergson (1978) já era bastante conhecido por Freud (2006), cujas ideias são incorporadas e criticadas por este em seu livro "Os chistes e a sua relação com o inconsciente", publicado em 1905. Para Freud, é possível compreender a lógica do inconsciente por meio dos chistes, ${ }^{5}$ situada não apenas nos sonhos e sintomas, mas também na vida cotidiana, nos atos falhos, nas práticas religiosas e na arte. A palavra chistosa, então, permite-nos apreender aquilo que está situado na ordem do recalcado, sem que o interlocutor pague o preço neurótico da angústia ou do padecimento dos sintomas.

Para Freud (2006), um novo chiste age de modo semelhante a um acontecimento de interesse universal, já que "passa de uma a outra pessoa como se fora a notícia da vitória mais recente" (p. 28). A formação de um chiste, por sua vez, ocorre a partir de determinadas técnicas, entre as quais: a condensação, formação e modificação de palavras; o múltiplo uso do mesmo material; o duplo sentido; o trocadilho; o deslocamento; o raciocínio falho; os chistes absurdos (o sentido nonsense); a resposta pronta; a ironia. Tais técnicas "evocam um sentimento de prazer no

\footnotetext{
${ }^{5}$ Cabe ressaltar que a expressão "witz", cuja raiz pode ser encontrada no romantismo alemão, servindo para designar tanto as tiradas ferinas que têm a forma de uma sentença sarcástica, quanto as anedotas em forma de historieta, é de difícil tradução para o português. Na edição brasileira, traduziu-se como "chiste", mas, por ser um termo com o qual temos pouca intimidade, alguns estudiosos preferem nomear de "anedota" e outros como "piada" (SLAVUTZKY; KUPERMANN, 2005, p. 7).
} 
ouvinte" (p. 95) e, assim, a atividade chistosa não pode ser concebida como inútil ou desinteressada (p. 96).

Há duas espécies de chistes, considerando-se o efeito perturbador que pode ou não produzir, os abstratos ou inocentes, os quais possuem um fim em si mesmos, e os tendenciosos, aqueles que se prestam a um fim (FREUD, 2006, p. 91). Sobre o propósito dos chistes, os tendenciosos dificilmente provocam a explosão do riso e, por outro lado, os "triviais" ou "carentes de substância" são fontes de muito prazer (p. 97). Estes são tidos como irresistíveis e podem servir a dois propósitos: "ou será um chiste hostil (servindo ao propósito de agressividade, sátira ou defesa) ou um chiste obsceno (servindo ao propósito de desnudamento)" (p. 97).

Freud (2006) volta-se, em primeiro lugar, aos chistes desnudadores, os quais se apresentam, quase sempre, uma linguagem pornográfica (smut), devido a serem motivados pelo desejo de desvelar aquilo que é sexual. Por sua vez, aquele que ri do smut é tido como "expectador de um ato de agressão sexual" (p. 98). Na perspectiva freudiana, esta espécie de chiste é preferida, com raras exceções, pelo sexo masculino. Desta forma, os chistes desnudadores permitem liberar o preconceito, por exemplo, contra os homossexuais, sob tom jocoso, emergindo um incômodo silenciado e igualmente desconhecido.

A estrutura dos chistes tendenciosos situa em torno de três pessoas (FREUD, 2006, p. 100), quer dizer, aquela que produz o chiste, o alvo "que é tomada como objeto da agressividade hostil ou sexual" e o destinatário onde "cumpre o objetivo do chiste a produzir prazer". O que permite ao enunciado indecente valer-se de "fontes de prazer além daquelas abertas aos chistes inocentes", cujo prazer está de algum modo vinculado à técnica (p. 101-102). Se o prazer vincula-se a uma técnica, os chistes tendenciosos tendem ao prazer da superação de um obstáculo para a satisfação de um instinto (p. 102). O qual inclina-se a um propósito hostil, promovendo a misoginia, a homofobia, o racismo, etc.

Desde a infância, os impulsos hostis contra o nosso próximo têm-se sujeitado às mesmas restrições, assim como nossas tendências sexuais (FREUD, 2006, p. 102). Os chistes permitem-nos "contornar" a proibição de certas hostilidades contra o nosso inimigo, tido como

\footnotetext{
${ }^{6}$ Sob o ponto de vista da Análise do Discurso, não há o que se falar em discursos "inocentes" ou "carentes de substância", devido a considerar que não existe neutralidade em língua(gem).
} 
"pequeno, inferior, desprezível ou cômico", ao qual superamos "por linhas transversas" (p. 103). Logo, a crítica insultuosa dirige-se não somente àquelas pessoas em posições elevadas, mas também a algumas instituições, à imagem de pessoas indefesas (p. 104) e ao sujeito enquanto pessoa coletiva (p. 110), tal como os homossexuais.

Em virtude disso, os chistes não se restringem ao riso, pois "não podemos excluir a possibilidade de que a produção dos chistes também partilhe outros motivos" (FREUD, 2006, p. 135). A maior parte dos chistes circulam anonimamente, mas se deve ter em mente que "ninguém se contenta em fazer um chiste apenas para si” (p. 138). Em oposição, o texto cômico permite rir até mesmo sozinho, sendo suficiente apenas o comediante e o objeto ou o alvo (p. 138-139). O sucesso dos chistes, por sua vez, exige que o enunciatário não cultive um sentimento contrário aos propósitos daquilo que é enunciado (p. 144-147).

Os estudos acerca do inconsciente, por sua vez, interessam à Análise do Discurso, no sentido de compreender a existência do sujeito, que se dá no próprio ato de enunciação (PÊCHEUX, 2009, p. 277). Até porque é através da língua(gem) que se manifestam incessantemente e sob mil formas - o lapso, o ato falho, etc. - os traços inconscientes do significante. O que implica considerar que o sujeito é efeito de linguagem, um ser que foi falado antes de falar, que traz um vestígio do discurso do Outro. ${ }^{7}$

Entre os objetivos desse trabalho, procura-se verificar os "efeitos de sentido" que circulam, no discurso humorístico, em torno do sujeito homossexual. Para tanto, é imprescindível desenvolver um breve histórico, na próxima seção, a respeito da homossexualidade masculina.

\section{Sobre as construções que permeiam a categoria homossexual}

Em termos de registro, a palavra "homossexual" surgiu num panfleto, publicado em 1869, e a sua autoria é atribuída ao jornalista austro-húngaro Karl Maria Kertbeny. As relações sexuais, por sua vez, entre pessoas do mesmo sexo, ingressaram no campo de projeção da ciência, com o artigo escrito pelo médico Karl Friedrich Otto Westphal, sobre as "sensações contrárias" (FOUCAULT, 2010, p. 50). Tão logo, a

\footnotetext{
${ }^{7} \mathrm{O}$ inconsciente, explica Mussalim (2000,p. 107), é o lugar do discurso do Outro, quer dizer, é onde emana o lugar da família, da lei, do pai, etc.
} 
conduta do sujeito homossexual passou a ser medida em relação à sua sexualidade, uma vez que nada daquilo que ele é, no fim das contas, escapa à sua sexualidade.

Até o século XIX, o pensamento religioso predominante no Ocidente concebeu a salvação como um mérito individual e sua busca como inerente ao próprio homem (FOUCAULT, 2004, p. 68). Sendo assim, a condição para a salvação consistia na obediência incondicional ao pastor, o representante da vontade divina (p. 69). O "sodomita", por sua vez, em desacordo com os dogmas cristãos, não poderia ser salvo. $\mathrm{O}$ que permitiu considerar a sodomia como justificativa para muitas desgraças. $\mathrm{O}$ cristianismo instaurou, então, por meio da sexualidade, uma espécie de poder regrador dos indivíduos (p. 71).

A ideia que traduz os homossexuais como homens com trejeitos efeminados remonta à metade do século XIX, uma vez que físicos, políticos, advogados, intelectuais e artistas representavam os homossexuais como homens efeminados, passivos e que ganhavam a vida com a prostituição nas ruas (GREEN, 2000, p. 63). Isto implica considerar que a homossexualidade só faz sentido no imaginário popular, quando a "normalidade" sexual é deixada à margem daquilo que se considera como padrão brasileiro de masculinidade.

Na virada do século XIX, o médico Francisco José Viveiros de Castro publicou, em 1894, as suas observações sobre a personalidade dos "uranistas". Estes foram retratados como caprichosos, invejosos, vingativos, ciumentos e instáveis, os quais passavam "rapidamente de um egoísmo à sensibilidade que chora", bem como incapazes de seguir "as profissões que demandam qualidades viris" (TREVISAN, 2000, p. 179). Os médicos da época, então, chegavam às mesmas conclusões adotadas pela religião cristã, frente à homossexualidade.

Outro médico higienista foi José Ricardo Pires de Almeida que, em 1906, publicou uma extensa monografia, defendendo que os uranistas, em maior parte, apresentavam um andar típico, rebolando as ancas e salientando as nádegas (GREEN, 2000, p. 90). Para ele, o tratamento da homossexualidade consistia em submeter o "doente" à leitura de romances, cuja beleza das formas femininas despertassem paixões, ou a se deitar com mulheres nuas ou trajadas como homens. E, de modo paralelo, eram recomendadas cerca de 30 a 100 sessões de hipnose com a finalidade de se "incutir ao doente a repulsão, o nojo, o horror em relação à sua anormalidade" (TREVISAN, 2000, p. 181). 
Até pouco tempo atrás, o Código Penal, instituído na década de 1940, em relação ao atentado violento ao pudor, considerava, em seu artigo 214, os atos libidinosos diversos da cópula vaginal. O que significava que a relação sexual era apenas a que acontece entre um homem e uma mulher, a qual se denominava "conjunção carnal". E, assim como a Igreja concebe em absoluto a relação entre homem e mulher, a lei penal refletia essa normalidade em seus artigos.

Entretanto, o Código Militar, instituído durante o regime militar, em relação à prática da homossexualidade, mantém, em seu artigo 235, como passível de penalidade e reprovação, toda relação sexual que não seja entre pênis e vagina. Desse modo, as relações que rejeitam a reprodução da espécie, conforme se pode perceber, são consideradas como libidinosas, devido a ensejar apenas o prazer.

Na década de 1980, a representação social do vírus do HIV era sinônimo de "homossexualidade" e, ao mesmo tempo, de morte. Os representantes de diversos setores da sociedade, então, em especial aqueles ligados à medicina e à Igreja Católica, responsabilizavam os homossexuais por adoecerem (TREVISAN, 2000, p. 442). Produzindo um sentido naturalizado de que somente os homossexuais (masculinos) poderiam ser portadores do vírus HIV (SOARES, 2012). A situação exigiu, portanto, que as diversas áreas da sociedade, as quais consideravam-se imunes à doença, empenhassem-se numa luta que passava a ser "de todos e não mais dos chamados grupos de risco" (p. 456).

Em relação à noção de "homossexualidade", houve mudanças significativas. Deixou de ser considerada uma doença pela Associação Psiquiátrica Americana, em 1980. No Brasil, o Conselho Federal de Medicina, em 1985, passou a homossexualidade do código 302.0, dentro da categoria de "desvio e transtorno sexual", para o código 206.9, sob a denominação "outras circunstâncias psicossociais". Em 1990, foi retirada do rol de patologias, pela Organização Mundial de Saúde (OMS). Por fim, o Conselho Federal de Psicologia, através da Resolução CFP n. ${ }^{\circ}$ 001/99, definiu como antiético o tratamento da "homossexualidade" como "desvio comportamental" ou "doença".

Contudo, a discussão acerca de um "tratamento" para a homossexualidade tornou a ganhar notoriedade com o polêmico Projeto de Decreto Legislativo n. ${ }^{\circ} 234 / 11$, conhecido como "cura gay". Tal projeto consistia em suspender a resolução do Conselho Federal de Psicologia, que pró́be aos psicólogos de considerarem a homossexualidade 
como patologia, além de tentarem mudar a orientação sexual de seus pacientes. Em 2013, a Comissão de Direitos Humanos da Câmara dos Deputados assentiu ao projeto em questão, o que resultou em uma série de manifestações pelo país.

Ante o exposto, podemos afirmar que a "homossexualidade" tem história, uma posição política. Desta forma, o "seu sentido não apenas marca outras formas de significar o homossexual, mas aponta para outros sentidos possíveis nesse embate de forças entre dizeres e a cristalização de conceitos" (SOARES, 2012, p. 120). A partir daí, procuramos compreender, no presente trabalho, a maneira como a imagem do homossexual é construída, num discurso que se importa em contestar uma visão que preconiza a "cura" para a homossexualidade.

\section{Sobre o esquete "Cura", uma análise do discurso humorístico}

AAD considera o contexto sócio-histórico como parte constitutiva do sentido (MUSSALIM, 2000, p. 123). Ela se interessa pelas condições em que o nosso objeto de análise - o esquete humorístico, nomeado como "Cura" -, por exemplo, foi produzido. Contextualizado num momento histórico em que os radicais religiosos brasileiros empenhavam-se em aprovar, na Câmara dos Deputados, uma proposta de "cura" para os homossexuais, nada mais representativo que o "Porta dos Fundos" como contraponto ideológico.

No vídeo, o ator Rafael Infante interpreta Jesus em uma sessão de "cura". Eis que surge Marcus Marjella, Sandrinho, com gestuais "efeminados", pedindo que seja curado de um "fogo que o consome". Após a sessão, os traços efeminados do rapaz persistem, deixando os "discípulos" atônitos, os quais julgavam, supomos, em virtude da forma como os diálogos, os silêncios compõem o vídeo, a homossexualidade como a doença a ser curada por Jesus. A referência ao projeto de "cura gay”, então, proposto pela "bancada evangélica”, não é nada sutil.

\footnotetext{
${ }^{8}$ CURA. Porta dos Fundos. 09/09/2013. Disponível em: < http://www.portadosfundos. com.br/video/cura $>$. Acesso em: 04 abr. 2015. (audiovisual)

${ }^{9}$ Criado em 2012, o "Porta dos Fundos" tem um nome bastante sugestivo, podendo ser associado à forma de "sexo anal", a saber, um tabu para a sociedade cristã. A partir daí, o referido canal vale-se de uma tonalidade de humor crítico, comumente dirigido às práticas de uma religião dogmática.
} 
Em virtude disso, podemos afirmar que todo discurso edifica-se a partir de uma rede interdiscursiva. A partir deste processo dialógico, a língua(gem), ora citando, ora comentando, ou parodiando outros discursos, permite disputar a verdade numa relação de aliança, de polêmica ou até mesmo de oposição. O que implica considerar que o discurso é uma arena de lutas em que os (inter)locutores, falando de posições ideológicas, sociais e culturais distintas, interagem e atuam uns sobre os outros (BRANDÃO, 2012, p. 22).

No início da cena, Jesus surge em pé, em cima de uma pedra alta e rodeado por uma multidão, que, em parte, encontra-se assentada sobre pedras menores ou de pé. Assim, o protagonista estende as suas mãos, chamando atenção de seus "fiéis", diz: "Oh, no 1". Dirige a sua face aos céus e põe-se a contar: " $5,4,3, \ldots$,. Ele vira o seu rosto à direita, em direção ao chão. Surge, então, aos pés do Cristo, um homem aparentemente morto. A contagem continua: "2, 1". Em seguida, Jesus ordena: "Lázaro, levanta-te e anda". A personagem que antes se encontrava "morta" é "ressuscitada" e, em simultâneo, grita: "eita". Logo, a multidão aplaude ao "milagre". Porém, o mestre comenta, de um modo um tanto engrandecedor, que o milagre por ele realizado "não é tão complicado".

O entendimento de uma produção de humor só é possível devido a ser construída através do saber já-dito sob a forma do pré-construído, do conhecimento partilhado (POSSENTI, 1998, p. 19), entre o falante e o ouvinte cristãos. Dessa forma, o esquete em análise mobiliza a personagem Jesus de acordo com o imaginário popular, caracterizada com uma longa barba, cabelos compridos, trajada com uma túnica. A partir daí, podemos averiguar que o discurso em análise é uma prática social que funciona pelo imaginário (PÊCHEUX, 1997, p. 82), no caso, cristão.

A heterogeneidade mostrada, de acordo com Maingueneau (1998, p. 78-79), pode ser marcada e não marcada. As formas marcadas são recuperadas no nível enunciativo, a partir de marcas linguísticas que mostram a presença de outra voz, tais como o discurso direto, o discurso indireto, as aspas e a glosa. Já as formas não marcadas são identificáveis sobre a face de índices textuais distintos, ou graças à cultura do coenunciador, como, por exemplo, o discurso indireto livre, a alusão, a imitação e a ironia.

Em vista disso, o milagre da ressurreição, cuja cena é (re) produzida no corpus em análise, consiste num recorte de tempo. 
Isto significa que, em algumas culturas, muito provavelmente não se reconheçam nem a cena, nem Jesus e nem as suas palavras. Por outro lado, identificamos sem muita dificuldade, quando Jesus diz "Lázaro, levanta-te e anda" ${ }^{10}$ como uma remissão ao Evangelho, pois somos interpelados por uma ideologia cristã. Dessa forma, a heterogeneidade mostrada e não marcada ocorre na medida em que o locutor produz, embora de modo não explícito, em nível do discurso, formas detectáveis que inscrevem o outro (MAINGUENEAU, 1998, p. 78-79).

Embora se configure como essencialmente humorística, a cena em análise é validada por meio de elementos do discurso religioso. O que permite ao (inter)locutor deparar-se com a situação limite da morte, pela qual confronta-se com a sua finitude. A partir daí, a desigualdade - isto é, a imortalidade e a mortalidade - instala, aos homens, a relação vida e morte (ORLANDI, 2003, p. 243). Surge, portanto, a necessidade de salvação para a vida eterna e, sob uma perspectiva cristã, o móvel para a salvação é a fé em Jesus. ${ }^{11}$

Na cena protagonizada, embora Jesus e Lázaro compartilhem do mesmo espaço sobre a pedra, só o primeiro está em pé e, de acordo com a crença, possui uma essência "imortal". Já a outra personagem, caracterizada por sua condição "mortal", surge aos pés de Cristo. O que se pode deduzir que Jesus ocupa um lugar à parte, em oposição aos ouvintes, constituídos como mortais, pois, "embora seja a parte acessível de Deus, é o próprio Deus” (ORLANDI, 2003, p. 246).

Nesta confluência, o Cristo é o sujeito que detém o poder de locução no discurso em análise, quer dizer, mais vale a palavra dele que a dos demais personagens. Não é à toa que a pedra mais elevada reserva-se a tal locutor. Sendo assim, podemos verificar que o objetivo da produção de humor não consiste em ofender a legitimidade do Cristo. $\mathrm{O}$ que será contestado, porém, ao longo da cena em análise, é a interpretação ortodoxa que alguns religiosos proferem à "condição homossexual".

De modo paralelo, a cena humorística distingue duas espécies de ouvintes, dentre os quais, em um primeiro plano, uma parte se acomoda sobre as pedras medianas, enquanto outra parte, em segundo plano, resta o desconforto de se manter em pé. Sendo assim, a interpretação deste

\footnotetext{
${ }^{10}$ João 11.43.

${ }^{11}$ Atos 16.31 .
} 
episódio passa pela memória, mais especificamente pelos prestígios sociais que alguns cristãos gozam, em detrimento dos demais.

Em vista disso, verificamos uma crítica que remete - considerandose a noção de interdiscurso - à própria formação da ética protestante, onde a preguiça e a indolência, assim como as riquezas que delas advenham, são consideradas como "pecados mortais" (WEBER, 2012, p. 127). Desta forma, o discurso em análise sugere que os cristãos conservadores, estruturados na vontade de poder, tornaram-se incapazes de se adaptarem às transformações da sociedade contemporânea.

Na cena em questão, há uma variedade significativa de símbolos, perpetrados historicamente por uma conjuntura religiosa, o que evidencia sua formação discursiva" (FD), a saber, "religiosa cristã". O discurso em questão, por outro lado, propõe que o pensamento religioso integrese à cultura moderna. Isto implica considerar que a FD é igualmente "progressista", ou "liberal". Então, os sentidos veiculados, no esquete em análise, deslocam-se entre um ponto de vista ortodoxo e outro liberal do cristianismo.

Com efeito, uma religião é na verdade uma multidão de religiões distintas e, por vezes, contraditórias (ORLANDI, 2003, p. 248). Assim, a heterogeneidade social e ideológica coloca, por exemplo, a existência de uma teologia progressista e outra mais conservadora. A partir daí, a condição homossexual é (re)pensada por uma corrente e, ao mesmo tempo, rejeitada por outra. Sendo assim, o confronto de forças entre as posições adotadas pelos diferentes segmentos da religião, especialmente, em relação à homossexualidade, é chamado de formações ideológicas (MUSSALIM, 2000, p. 124).

Cabe ressaltar que, dadas as relações de força existentes, a formação social constitui-se como heterogênea. Não obstante, o sentido produzido pelas/nas instâncias de poder, assim, colocado em circulação, pode ser considerado hegemônico e produzir efeitos ideológicos de unicidade (MARIANI, 2001, p. 108). O que implica considerar que as igrejas, sobretudo aquelas do segmento Pentecostal, mas também a Católica, produzem efeitos hegemônicos sobre o sujeito homossexual, sendo significado como pecador, doente e anormal.

${ }^{12}$ A formação discursiva, de acordo com Michel Foucault (2005, p. 43), é definida como um conjunto de regras que, a partir do lugar que o sujeito ocupa, determina aquilo que pode/deve ser dito. 
Durante o processo de realização do "milagre", a personagem Jesus procura criar uma expectativa em relação aos enunciatários, utilizando-se de uma contagem regressiva $(5,4,3, \ldots 2,1)$. Tal mecanismo permite desconstruir a imagem que a ortodoxia teve produzido em torno da divindade cristã. Para tanto, a contagem evoca a representação que o interlocutor faz a respeito de um mágico. A cena em análise, por conseguinte, visa reforçar a ideia de um Cristo que, embora seja Deus, possui certa "humanidade". ${ }^{13}$

Jesus: "próximo". Sandrinho: "sou eu, Senhor... sou eu... desculpa é que está cheio de pedra aqui...". Jesus: "tudo bem?". Sandrinho: "tudo ótimo... então, é isso...". Jesus: (é isso) "o quê?". Sandrinho: "é isso... o que falaram... ouvi falar... ouvi falar dessas coisas do milagre... das coisas que você está fazendo... a cura... no bairro só se fala nisso... daí vim aqui ser testada". Jesus: "mas, o quê que você tem?". Sandrinho: "eu tenho um fogo... eu tenho um fogo incontrolável... me queimando por dentro, que não aguento mais... não aguento mais, Senhor... preciso de ajuda". Jesus: "desculpa, acho que não entendi exatamente o quê que você quer". Sandrinho: "preciso que o Senhor me livre desse mal... dessa maldição que me corrói... eu não aguento mais...". Jesus: "éééé... tá... eu vou tentar... tentar te ajudar...". Sandrinho: "uhum". (CURA, 2013)

Após o episódio da ressurreição, Jesus chama, de acordo com a ordem de chegada, o próximo para ser atendido. Tal expressão remete o (inter)locutor, considerando-se a noção de interdiscurso, ${ }^{14}$ à imagem que se faz tradicionalmente de um médico. Sendo assim, o papel da memória discursiva consiste em reafirmar a ideologia cristã, na qual Jesus é mobilizado como o "médico dos médicos". ${ }^{15}$ A intervenção divina, portanto, ocorre num nível espiritual e, então, a lógica é de que Jesus tenha maior poder que os médicos do plano temporal.

Por sua vez, a situação torna-se inusitada, na medida em que o "próximo" sujeito manifesta-se com certos traços efeminados. Assim, o

\footnotetext{
${ }^{13}$ João 1.14.

${ }^{14} \mathrm{O}$ interdiscurso, de acordo com Eni Orlandi (2000, p. 31), é um conjunto de formações elaboradas, embora já esquecidas, e que sustentam a possibilidade mesma do dizer. 15 Atos 2.22 .
} 
imaginário cristão também possui um protótipo para o gênero masculino, o qual deve ser consoante com a "normalidade" do heteroerotismo monogâmico (BRITZMAN, 1996, p. 79). Desta forma, a graça da cena em análise situa-se em torno de uma personagem, cujos "gestuais" por ela utilizados rompem com o "padrão" de masculinidade do (inter) locutor brasileiro.

Na cena protagonizada, o funcionamento da língua(gem) assentase na tensão existente entre dois processos (ORLANDI, 2000, p. 36). Os parafrásticos são aqueles pelos quais em todo dizer há sempre algo que se mantém. Já os polissêmicos representam o deslocamento de processos de significação. O que vemos, por exemplo, num primeiro momento, é a ruptura do quadro humorístico com o processo de língua(gem), que põe em conflito os discursos acerca de um "tratamento" para a homossexualidade. Isto implica considerar que os sentidos não são esgotáveis, uma vez em todo dizer há sempre a possibilidade de uma abertura para a polissemia (ORLANDI, 2000, p. 36).

Mas, a cena em questão, na medida em que permite uma leitura a partir dos estereótipos sobre a homossexualidade, obedece a um estrito processo dominado pela (re)produção de dizeres machistas. $\mathrm{O}$ que justifica uma personagem que surge por meio do estereótipo de um homem com trejeitos efeminados. Tal sujeito utiliza-se inclusive de expressões que concordam, em língua portuguesa, com o gênero feminino ("vim aqui ser testada"). É possível verificar, então, a estabilidade de dizeres sedimentados em uma cultura patriarcal, onde as características masculinas de um sujeito que não se figura como macho são apagadas.

Além disso, a personagem homossexual, devido aos seus trejeitos efeminados, migra tão rapidamente de um estado de espírito, como diria Viveiros de Castro, a uma "sensibilidade que chora" (TREVISAN, 2000, p. 179). Se não bastasse, o próprio site do "Porta dos Fundos" aduz que "certas 'doenças' não precisam de cura" (CURA, 2013). Isto não significa que a homossexualidade não possa vir a ser considerada como uma "patologia", só não é passível de "cura". O discurso em análise, portanto, constitui-se, de igual modo, como um retorno aos dizeres (re) produzidos pelos médicos higienistas.

Em certo momento, a personagem em questão, que mais tarde identifica-se como Sandrinho, acusa as "pedras" de obstruírem a sua caminhada até Jesus (“desculpa, é que está cheio de pedra aqui”). Evidentemente, o episódio em questão consiste em uma crítica ao 
"dogmatismo religioso", ou mais propriamente à "bancada evangélica". Assim, o interdiscurso permite que o leitor cristão evoque na memória, a respeito da ortodoxia cristã, um sentido bíblico, a saber, "pedra de tropeço". ${ }^{16}$

A personagem Sandrinho, quando questionada por Jesus, a respeito do problema que o afligia, enuncia padecer de um "fogo" ("eu tenho um fogo... incontrolável..."). Logo, a interpretação desta cena evoca pela memória, especificamente, um sentido "sexual" para a palavra "fogo". Isto pois, a primeira das técnicas para a obtenção do fogo resulta de uma fricção, um movimento de vaivém (CHEVALIER; GHEERBRANT, 2009, p. 442). De tal modo, o termo "fogo" não poderia comportar outro sentido, que fosse distinto de uma conotação "sexista", a fim de explicar um desconforto íntimo, sentido por um sujeito que não atende aos padrões de masculinidade do interlocutor brasileiro.

Jesus estende a mão esquerda. Há um momento de silêncio. Sandrinho: "nooossa... linda a sua bata... comprou aqui em Jerusalém mesmo?". Jesus: "só um instantinho". Sandrinho: "é linho?". Jesus: "algodão... vamos respirar". Sandrinho: " $100 \%$ algodão egípcio, 700 fios... adoooro... tem um amigo meu que vende, né... numa tendinha lá no Egito... na Aristides Espínola... esquina com o rio Nilo... se você quiser... te dou um desconto, tá?". Jesus: "vamos ficar calmo... você é ansioso, né? você tem coisas boas na sua personalidade... fica calmo". Sandrinho: "desculpa... hummm...". Jesus: "vamos concentrar". Sandrinho: "nooossa, seu cabelo é maravilhoso, Jesus... babado, hein... você usa o quê? babosa? ou aquele óleo do Marrocos, que está todo mundo usando? sou super entendida... ôoow... eu sei de tudo". Jesus: “amigo, olha só...”. O rapaz: "Sandriiinho... me chama de Sandriiinho?". Jesus: “ouça, só... presta atenção... eu preciso me concentrar para poder te ajudar... prestou atenção nisto?". Sandrinho: "desculpe". (CURA, 2013)

Como se vê, o processo de expulsão do mal é marcado por toda uma ritualização ("Jesus estende a mão", "fecha os olhos", etc.), na qual é submetida a personagem Sandrinho. O que se pode observar é

\footnotetext{
${ }^{16}$ Mateus 18.6-7.
} 
que a relação de "informalidade", contida na produção de humor, não é suficiente para alterar o estatuto jurídico do locutor. Isto porque o fato da personagem falar diretamente com a divindade cristã, não modifica o seu poder de dizer, o lugar de quem recebe o milagre. A partir daí, o desnivelamento entre locutor (o Cristo) e interlocutor (o homossexual) mantém-se, pois, "de um lado, temos a onipotência divina, de outro, a submissão humana” (ORLANDI, 2003, p. 247).

Entretanto, Sandrinho parece não compreender as regras para que o milagre seja realizado, até porque ele rompe constantemente o silêncio dramatizado por Jesus. De tal maneira, a graça da cena em análise reside no desajeitamento de uma personagem que, embora devesse falar do lugar de quem recebe uma cura, enuncia de um lugar de "intimidade" com o Cristo. Assim, os efeitos de sentido, produzidos pela quebra do silêncio em questão, permitem corrigir o comportamento de um sujeito, cujas práticas rompem com as formas convencionais de relação entre homem e mulher.

Se não bastasse ser consagrado como efeminada, Sandrinho mostra-se intimamente atraída pelo universo da moda ("linda a sua bata", "100\% algodão egípcio", "700 fios", etc.). Assim, a interpretação deste trecho evoca, por meio da memória discursiva, como essencialmente femininos, os trabalhos ligados às indústrias da moda e da costura. A partir daí, podemos perceber um discurso que, na perspectiva dos médicos higienistas (TREVISAN, 2000, p. 179), associa os homossexuais masculinos aos papéis sociais atribuídos ao feminino, construindo, e reforçando também, um lugar muito específico para o que pode/deve ser próprio do homem e, por oposição, o que pode/deve ser próprio da mulher, numa percepção binária da sexualidade.

Na sequência, Sandrinho demonstra também um afeiçoamento em relação ao segmento da beleza e da estética ("seu cabelo é maravilhoso", "você usa o quê?", "é babosa?"). O que redunda em discursos discriminalizadores e, ao mesmo tempo, essencializantes. Desta forma, a cena protagonizada, na medida em que o sujeito em questão é restringido a determinados segmentos profissionais, permite manutenção de uma ideologia patriarcal.

A formação imaginária a respeito do sujeito homossexual é reforçada pelas escolhas lexicais realizadas por Sandrinho ao se referir aos cabelos do Cristo. Este poderia escolher, por exemplo, entre "fantástico" ou "incrível", mas optou por uma expressão tipicamente gay, quando 
enuncia “babado, hein”. Daí, então, este recurso de linguagem mobiliza os estereótipos sobre a homossexualidade, a fim de cultivar no interlocutor certa expectativa, em relação a tudo o que se disse sobre a cura.

Em vista disso, o silêncio representa aquilo que não se diz na materialidade linguística, mas que se encontra alojado no interior desta (ORLANDI, 2007, p. 105). De tal modo, o silêncio consiste como objeto de interpretação, pois a sua quebra é o que permite situar um sujeito à margem da sociedade heterossexual e, ao mesmo tempo, (re)produzir efeitos de anormalidade, devido à inversão de papéis de gênero socialmente estabelecidos. É possível verificar, então, que a homossexualidade não faz sentido fora dos lugares já estabelecidos pelos discursos religioso, médico e machista.

Jesus: "vamos ficar calminho? você precisa se con...". Sandrinho: "centrááá...". Jesus: "que eu tô querendo ajudar o cole...". Sandrinho: "guiiiinhaaa". Jesus: "isso... vamos lá?". Jesus: "foi (embora o mal que afligia ao rapaz)". Sandrinho: "geeeente, tô ótima... tá aí... tô cem por centa...". As pessoas, dentre a multidão, se olham, sem entender nada. Sandrinho: "não tô acreditando, Jesus (com a pronúncia em inglês do nome do 'mestre'). Ele dá três beijinhos, alternadamente em cada lado do rosto de Jesus. Sandrinho: "obrigada por tudo, viu? tem que pagar alguma coisa? não vai me chamar de caloteira depois, não... hein?". Sandrinho retira-se, dizendo: "você é louca". Jesus (responde ao povo): "o quê, gente? gastriiiite". (CURA, 2013)

No trecho acima, é possível averiguar uma ideologia androcêntrica (BOURDIEU, 2005, p. 18), onde a imagem de Jesus constrói-se, em detrimento de Sandrinho, que se constitui emocionalmente instável. Assim, o sujeito macho é significado como alguém capaz de exercer tanto o controle da situação, quanto o controle do outro, do não macho. O que implica considerar um sujeito em conformidade com o Adão bíblico, o qual foi instituído por Deus para que "dominasse" sobre todas as "coisas". ${ }^{17}$ Contudo, o sujeito em questão, se não bastasse ser a imagem e semelhança de Deus, é ainda o próprio Deus (ORLANDI, 2003, p. 247).

${ }^{17}$ Gênesis 1.26. 
Em seguida, Jesus emprega uma técnica comum, em se tratando de imaginário sobre os educadores, em que estes solicitam aos alunos que completem os sentidos das palavras, de modo que compreendam melhor aquilo sobre o que se diz. Sendo assim, a produção humorística consiste pelo atravessamento do discurso pedagógico. O que permite educar uma personagem que, embora devesse falar de um lugar de quem recebe uma cura, insiste em enunciar de um lugar de "intimidade" com o Cristo.

A graça do trecho em análise advém, em um primeiro momento, de uma personagem que, mesmo após à sessão de cura, permanece efeminada. Tão logo, Sandrinho (re)produz enunciados que concordam, na língua portuguesa, com o gênero feminino ("tô ótima"). Evidentemente, o uso de "cem por centa", em lugar de "cem por cento", que de acordo com a gramática é invariável, opera um trocadilho entre o numeral "cento" e o verbo "senta". Além do que, nesse imaginário sobre a homossexualidade masculina, recorre-se comumente à aproximação entre este universo e o universo feminino, aqui exagerado (nas expressões no gênero feminino), devido aos efeitos de sentidos pretendidos com o esquete em análise. Com isso, a homossexualidade, considerada, sob uma formação discursiva religiosa, médica e machista, como vergonhosa e moralmente inferior, torna-se objeto de riso.

Cabe pontuar que a memória discursiva exerce um importante papel na deflagração de efeitos de humor que se instalam no corpus em análise. Assim sendo, a condição do riso situa na capacidade do interlocutor fazer uma leitura por conta das cristalizações sobre o que é ser gay. $\mathrm{O}$ que não significa dizer que a personagem caracterizada com trejeitos efeminados seja de fato homossexual. Dessa forma, a nossa perspectiva seria a de que fosse porque estamos nessa formação discursiva, que nos permite reconhecê-lo pelo já-lá sobre a (homo)sexualidade.

Em outro momento, o efeito de humor decorre da resposta inesperada de Jesus, ao enunciar que o "problema" de Sandrinho consistia em uma "gastrite". O que permite interpretar que a sexualidade não seja uma questão para o mestre. Sendo assim, o Cristo parece zombar dos religiosos que o seguiam, frustrando-lhes a expectativa. Aliás, a própria inscrição contida no site, onde se encontra hospedado o vídeo em análise, significa os cristãos dogmáticos como "falsos milagreiros", pois não enxergam que certas "doenças" não precisam de cura. Dessa forma, a corrente conservadora, que prega uma possibilidade de cura aos homossexuais, constitui-se também como alvo de riso. 
Com efeito, é possível verificar que, em uma formação discursiva, existe sempre a presença do Outro, que confere ao discurso o caráter de ser heterogêneo (MUSSALIM, 2000, p. 129). E, embora o sujeito enuncie de um lugar ideológico progressista, os embates entre este lugar e o dogmatismo são recuperáveis no interior mesmo do discurso. Sendo assim, a produção humorística, quando ironiza a religião conservadora, negando-a através de uma paródia, recupera-a como parte constitutiva do discurso.

\section{Conclusão}

No discurso humorístico, encontram-se cristalizadas as diversas manifestações culturais e ideológicas. O que implica considerar que o nosso corpus de análise (no caso, um esquete produzido pelo canal "Porta dos Fundos", cujo título é "Cura") não deve ser entendido apenas como um instrumento de diversão. Até porque o discurso de humor, como qualquer outro, tem a sua regularidade, o seu funcionamento, que "é possível apreender se não opomos o social e o histórico, o sistema e a realização, o subjetivo ao objetivo, o processo ao produto" (ORLANDI, 2000, p. 22).

Em vista disso, o presente trabalho consistiu em examinar quais eram os efeitos de sentido que circulavam, no discurso contido em uma produção de humor, a respeito da homossexualidade masculina, frente a uma "proposta de cura gay", apresentada por um segmento conservador do cristianismo. Neste sentido, o corpus analisado constitui-se como uma arena de lutas, onde os (inter)locutores, falando de posições ideológicas, sociais e culturais distintas, interagem e atuam uns sobre os outros (BRANDÃO, 2012, p. 22).

O que apreendemos imediatamente é que a cena protagonizada, embora se configure como essencialmente humorística, valida-se a partir de elementos do discurso religioso. Sendo assim, o (inter)locutor, a princípio, é induzido a se deparar com a situação limite da morte, pela qual surge a necessidade de salvação para a vida eterna. Além disso, a cena em questão se apropria de uma variedade significativa de símbolos, os quais são perpetrados historicamente por uma conjuntura religiosa. A partir daí, verificamos que o corpus analisado inscreve-se em uma Formação Discursiva (FD), a saber, religiosa cristã. 
Nesta confluência, observamos que o esquete analisado importase, num primeiro momento, em reconsiderar os dizeres que sustentam uma "proposta de cura" para a homossexualidade. Não obstante, a cena em questão, num segundo momento, dialoga com os processos de linguagem dominados pela (re)produção de dizeres sedimentados nas FDs religiosa, médica e machista. O que justifica um sujeito marcado pela feminilização de seus trejeitos, de seu vocabulário, de seus interesses em torno da moda, etc. Em virtude disso, o riso produzido, sobre a homossexualidade masculina, reside na capacidade do interlocutor compartilhar as cristalizações sobre o que é ser gay.

Contudo, a produção humorística em voga permite desfazer os estereótipos de gênero, na medida que os valores cristalizados pela religião dogmática, no que tange à homossexualidade, passam a ser questionados. Isto permite que se possa rir também desses valores "naturalizados" a partir do que Jesus cura. Ou seja, não a homossexualidade, já que esta pouco importa na veiculação do esquete (à qual é realocada a uma outra categoria, a da normalidade), mas a gastrite que aflige a personagem de nome Sandrinho.

Por fim, é importante ressaltar que o deslocamento produzido, em termos históricos, contribui de igual modo para a produção do riso. Neste sentido, podemos observar que a vida de Jesus, em uma época remota, é atualizada em termos de localização (a referência aos pontos de venda, na fala de Sandrinho, ou ao bairro onde este ouviu falar sobre as curas realizadas por aquele etc.), de tratamento de beleza (babosa para os cabelos) ou ainda sobre o tecido da bata de Jesus ser cem por cento de algodão egípcio etc.

\section{Referências}

BAKHTIN, M. Estética da criação verbal. São Paulo: Martins Fontes, 2011.

BERGSON, H. O riso: ensaio sobre a significação do cômico. Trad. Nathanael C. Caixeiro. Rio de Janeiro: Zahar Editores, 1899; 1978.

BOURDIEU, P. A dominação masculina. Trad. Maria Helena Kuhner. 4. ed. Rio de Janeiro: Bertrand Brasil, 2005. 
BRANDÃO, H. H. N. Enunciação e construção de sentido. In: FIGARO, R. (Org.). Comunicação e Análise de Discurso. São Paulo: Contexto, 2012. p. 19-43.

BRITZMAN, D. P. O que é esta coisa chamada amor: identidade homossexual, educação e currículo. Revista Educação e Realidade, Porto Alegre, v. 21, n. 1, p. 71-96, jan.-jun. 1996.

CHEVALIER, J.; GHEERBRANT, A. Dicionário de símbolos. Trad. Vera da Costa e Silva. 24. ed. Rio de Janeiro: José Olympio, 2009.

CURA. Porta dos Fundos. 09/09/2013. Disponível em: <http:// www.portadosfundos.com.br/video/cura>. Acesso em: 4 abr. 2015. (audiovisual)

FOUCAULT, M. Ética, sexualidade, política. Rio de Janeiro: Forense Universitária, 2004.

FOUCAULT, M. Arqueologia do saber. 7. ed. Rio de Janeiro: ForenseUniversitária, 2005.

FOUCAULT, M. História da sexualidade I: a vontade de saber. Trad. Maria Thereza da Costa Albuquerque et al. 20. reimp. Rio de Janeiro: Edições Graal, 2010.

FREUD, S. Os chistes e sua relação com o inconsciente. v. VIII (1905). Direção da edição brasileira de Jayme Salomão. Rio de Janeiro: Imago, 1905; 2006.

GONÇALVES; J. A. T.; FERREIRA, N. C. Testemunhos de conversão de egressos do sistema prisional: discurso, religião e ideologia. Revista Estudos da Linguagem, Belo Horizonte, v. 22, n. 2, p. 195-217, jul.-dez. 2014

GREEN, J. N. Além do carnaval: a homossexualidade masculina no Brasil do século XX. São Paulo: Editora da Unesp, 2000.

MAINGUENEAU, D. Temas-chave da análise do discurso. Belo Horizonte: UFMG, 1998.

MARCUSCHI, L. A. Gêneros textuais no ensino de língua. In:

Produção textual, análise de gêneros e compreensão. São Paulo: Parábola Editorial, 2008. 
MARIANI, B. A institucionalização da língua, história e cidadania no Brasil do século XVIII: o papel das academias literárias e da política do Marquês de Pombal. In: ORLANDI, E. P. (Org.). História das ideias linguísticas: construção do saber metalinguístico e constituição da língua nacional. Campinas: Pontes, 2001.

MUSSALIM, F. Análise de Discurso. In: __ _ ; BENTES, A. C. (Org.). Introdução à linguística II: domínios e fronteiras. 3. ed. São Paulo: Cortez, 2000. p. 101-142.

ORLANDI, E. P. Análise de discurso: princípios e procedimentos. Campinas: Pontes, 2000.

ORLANDI, E. P. A linguagem e seu funcionamento: as formas do discurso. 2. ed. Campinas: Pontes, 2003.

ORLANDI, E. P. As formas do silêncio: no movimento dos sentidos. 6. ed. Campinas: Editora da Unicamp, 2007.

PÊCHEUX, M. Análise automática do discurso (AAD-69). In: GADET, F.; HAK, T. (Org.). Por uma análise automática do discurso: uma introdução à obra de Michel Pêcheux. Trad. Bethania S. Mariani et al. 3 . ed. Campinas: Editora da Unicamp, 1983; 1997. p. 61-105.

PÊCHEUX, M. Semântica e discurso: Uma crítica a afirmação do óbvio. Trad. Eni P. Orlandi et al. 4. Ed. Campinas: Editora da Unicamp, 2009.

POSSENTI, S. Os humores da língua: análise linguística de piadas. Campinas: Mercado de Letras, 1998.

POSSENTI, S. Humor, língua e discurso. Campinas: São Paulo: Contexto, 2010.

RASKIN, V. Semantic Mechanisms of Humor. Dordrecht: D. Reidel, 1985.

SLAVUTZKY, A.; KUPERMANN, D. In.: . (Org.). Seria trágico... se não fosse cômico: humor e psicanálise. Rio de Janeiro: Civilização Brasileira, 2005.

SOARES, A. S. F. Doente e pecador: ecos do século XIX sobre a homossexualidade na imprensa oficial (1985-2010). In: TASSO, I.; NAVARRO, P. (Org.). Produção de identidades e processos de subjetivação em práticas discursivas. Maringá: Eduem, 2012. p. 111-129. 
TREVISAN, J. S. Devassos no paraíso: a homossexualidade no Brasil, da colônia à atualidade. 3. ed. Rio de Janeiro: Record, 2000.

WEBER, M. A ética protestante e o espírito do capitalismo. Trad. Pietro Nassetti. São Paulo: Martin Claret, 2012.

WEINBERG, G. Society and the healthy homosexual. New York: Saint Martin's, 1972. 